\title{
EVOLUTION OF PATTERNS OF REGIONAL GROUNDWATER FLOW IN SOUTHEASTERN NEW MEXICO; RESPONSE TO POST-PLEISTOCENE CHANGES IN CLIMATE
}

\section{DISCLAIMER}

This report was prepared as an account of work sponsored by an agency of the United States Government. Neither the United States Government nor any agency thereof, nor any of their employees, makes any warranty, express or implied, or assumes any legal liability or responsibility for the accuracy, completeness, or usefulness of any information, apparatus, product, or process disclosed, or represents that its use would not infringe privately owned rights. Reference herein to any specific commercial product, process, or service by trade name, trademark, manufacturer, or otherwise does not necessarily constitute or imply its endorsement, recommendation, or favoring by the United States Government or any agency thereof. The views and opinions of authors expressed herein do not necessarily state or reflect those of the United States Government or any agency thereof.

\section{MASTER}

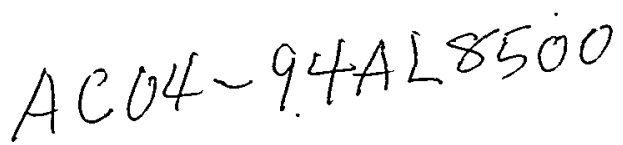




\section{DISCLAIMER}

Portions of this document may be illegible in electronic image products. Images are produced from the best available original document. 
Appendix A: Evolution of Patterns of Regional Groundwater Flow in Southeastern, New Mexico; Response to Post-Pleistocene Changes in Climate. Thomas F. Corbet, Sandia National Laboratories, Albuquerque, New Mexico, presented as a poster session, 1994 Annual Meeting of the Geological Society of America, Seattle, Washington, Oct. $24-27,1994$

\section{Introduction}

The Waste Isolation Pilot Plant (WIPP) is a potential repository for transuranic wastes generated by defense programs of the U.S. Department of Energy. The repository site is located $42 \mathrm{~km}$ east of the city of Carisbad, New Mexico in a thick, Permian-age deposit of bedded salt. One consideration in evaluating the performance of the repository is that a future society might inadvertently penetrate the repository with one or more drill holes. Given certain circumstances, these holes could provide a pathway for contaminated brine to move upward into relatively permeable strata located above the bedded salt. There is concern that flowing groundwater could then transport radionuclides laterally to the sub-surface portion of the accessible environment, currently defined by the disposal regulations as the region more than 5 kilometers from the radioactive waste. The simulations presented here are part of a numerical modeling study of the possible impact that a change in climate over the next 10,000 years could have on the pattern of groundwater flow and, consequently, on the migration of radionuclides in strata overlying the repository.

One previous modeling study has examined the long-term response of this hydrologic system to changes in climate. Davies (1989) used a cross-sectional model to simulate the transient response assuming an elevated initial water table and zero recharge over a 20,000 year period. His results confirmed that it is possible that this system drains slowly enough that it could sustain transient flow from the Pleistocene to the present without additional recharge.

In this study, we expand on the work of Davies by simulating flow in large three-dimensional region and by using rigorous free-surface and seepage-face boundary conditions. We assume that changes in climate influence regional groundwater flow by modifying the rate at which moisture percolates through the unsaturated zone to arrive at the water table. Once moisture reaches the water table, it recharges the saturated zone until the water table rises to the land surface. Moisture in excess of the amount required to maintain the water table at the land surface is removed by evapotranspiration or surface runoff.

We simulate the effects of climate on regional flow by treating the model region as a series of contiguous groundwater basins in which the water table moves in response to imbalance between the rate of recharge and the rate at which groundwater flows away from the water table. The model region encompasses multiple groundwater basins because the lateral boundaries separating these basins can move, or possibly be generated or destroyed, during the course of the simulations. The lateral boundaries of the model region follow the closest groundwater divides that we believe could be stationary for entire period of time simulated.

The simulations presented here suggest that the position and shape of the water table, and consequently the entire flow system above the salt, is sensitive to changes as small as a few hundredths of a centimeter per year in the rate of recharge to the saturated zone. If recharge is sufficient to maintain the water table near the surface, flow in confined units at depth follows the slope of local topography. Smaller recharge rates result in a deeper, flatter water table and flow in confined units is along the same direction as the regional slope of the land surface.

Flow rates and directions in confined units, however, respond too slowly to changes in recharge to remain in equilibrium with the current recharge rate. Instead, flow in these units probably remains in a transient state of adjustment to long-term changes in climate. 


\section{General Description and Capabilities}

- The SECO-3D (Knupp, 1995) code was specifically designed for both steady-state and transient regional groundwater flow calculations involving interactions between a free-surface water-table and a realistic topography.

- SECO-3D solves the rigorous free-surface equations (i.e., the kinematic or phreatic boundary condition).

- The equations solved by SECO-3D are an ordered approximation, therefore the code may be verified through grid convergence testing.

- SECO-3D uses a finite volume discretization to achieve second-order spatial accuracy. A fully-implicit first-order accurate time-stepping algorithm is used; there are no restrictions on time-step size due to stability requirements. A steady-state algorithm, developed as the limiting case of the transient algorithm, permits simulation of steady conditions.

- The code was designed for simulations that involve strongly heterogeneous and geometrically complicated stratigraphies. The use of 'inactive' cells permits simulations with complicated geometries. Recharge can be time-varying.

- The code presently uses a line-SOR solver to handle the 2000-to-1 cell aspect ratios used in this study. Future plans include instaliation of a three-dimensional multi-grid solver. 


\section{The Governing Equations}

Mass conservation requires that on the interior of the domain

$$
\nabla \cdot \mathrm{K} \quad \nabla h=s_{s} \frac{\partial h}{\partial t}
$$

with hydraulic head $h$ as the dependent variable, $\mathrm{K}$, a spatially-dependent conductivity tensor, and $S_{s}$ the specific storage. No-flow boundary conditions are imposed on the bottom and vertical sides of the domain, while the following pair of conditions are imposed on the top boundary representing the free-surface:

$$
\begin{aligned}
h\left(x, y, z_{w t}, t\right) & =z_{w t}(x, y, t) \\
(\mathrm{K} \cdot \nabla h+N) \cdot \nabla(h-z) & =s_{y} \frac{\partial z_{w t}}{\partial t}
\end{aligned}
$$

(Bear and Verruijt, 1987)

where $z_{w t}$ is the elevation of the water-table, $N$ is the normal flux due to recharge and/or evapotranspiration, and $S_{y}$ is the specific yield.

\section{The Moving Mesh}

The code uses a moving mesh to track the location of the free-surface. The main advantage of the moving mesh is that a finite volume discretization can be used that is second-order spatially accurate even on the boundary. The principle disadvantage of the moving mesh is that it is difficult to maintain grid alignment with stratigraphic layers; SECO-3D addresses this problem by keeping the computational mesh aligned with the stratigraphy except near the water-table surface. Another disadvantage of the moving mesh is that when the water-table position is updated, material properties must be interpolated from the stratigraphic database onto the computational mesh. Because the interpolations are one-dimensional they are not expensive. 


\section{Seepage Condition}

The kinematic condition is applied wherever the water-table elevation is below the land surface. If the water-table elevation is the same as the land surface, the kinematic condition may need to be converted to a seepage face. The seepage boundary condition is

$$
h\left(x, y, z_{w t}, t_{w t}\right)=z_{L S}(x, y)
$$

where $z_{L S}$ is the local land surface elevation and $t_{w t}$ is the time at which the water-table encounters the land-surface. To determine whether the kinematic or the seepage boundary condition should be applied, the vertical speed of the water-table, $\frac{\partial z_{w t}}{\partial t}$,

is computed. The algebraic sign of the quantity indicates whether or not the water-table is rising or falling. If the water-table at a particular location is rising, the seepage condition is enforced there. If the water-table is falling, the kinematic condition is applied.

\section{Picard Iteration}

The numerical algorithm consists of an intra-time-step Picard iteration having the following steps:

- The stencil coefficients of the discrete system are calculated from the provisional water-table solution.

- The linearized equations are relaxed until the scaled residual is less than the user-specified tolerance.

- An outer-residual for the water-table boundary condition is computed.

- A 'convergence' test is applied to the outer and scaled residuals. If the tolerances are not satisfied, the water-table position is updated from the boundary conditions and the intra-time-step iteration continues. Otherwise, the calculation proceeds to the next time-step. 
Two steady-state calculations were performed to demonstrate the sensitivity of the flow fieid to the assumed recharge rate. The calculations contrast flow conditions for rates of maximum potential recharge of 0.1 and $0.01 \mathrm{~cm} / \mathrm{yr}$.

The larger recharge rate is sufficient to maintain the water table at the land surface except in the regions where the land surface is at high elevation. Figure 11 shows that the depth of the water table is zero over most of the model region and 40 to 80 meters under topographic highs.

Consequently, the water table (Figure 12) reflects local features of the land surface. In contrast, the depth to the water table, if recharge is $0.01 \mathrm{~cm} / \mathrm{yr}$ (Figure 13), is more than 80 meters over more than half of the model region. The water table at this recharge rate (Figure 14) is a flatter and smoother surface which slopes north-to-south along the regional topographic gradient.

The shape of the water table exerts a clear control on potentiometric surfaces of confined units at depth. The potentiometric surface of the Culebra dolomite, for example, is similar to that of the water table. Figures 15 and 16 show the potentiometric surface of the Culebra dolomite for recharge rates of 0.1 and $0.01 \mathrm{~cm} / \mathrm{yr}$ respectively.

The sensitivity of the flow field to the amount of recharge has implications for the performance of the WIPP repository. Figures 17 and 18 show vectors of flow in the Culebra for the two steadystate calculations. Given a recharge rate of $0.1 \mathrm{~cm} / \mathrm{yr}$, flow from the vicinity of the WIPP is toward the west. A recharge rate of $0.01 \mathrm{~cm} / \mathrm{yr}$ results in flow toward the south.

Steady-state calculations demonstrate that the modeled flow system is sensitive to the amount of recharge but do not provide information about the time required for the flow system to respond to changes in recharge. We performed a transient calculation to simulate the change in recharge shown in Figure 10. The highest and lowest recharge rates used for the transient calculation are the same as those for the steady-state calculations. We assumed a compressibility of $5 \times 10^{-9} \mathrm{~Pa}^{-1}$ and a specific yield of 0.05 for all hydrostratigraphic units. The initial condition is the steady-state flow field calculated for a recharge rate of $0.1 \mathrm{~cm} / \mathrm{yr}$.

Figures 19, 20, and 21 show how the simulated potentiometric surface of the Culebra dolomite changed with time. The potentiometric surface drops and flow directions rotate toward the south as the recharge rate declines during the 6,000 year period starting 14,000 years ago. This trend continues at an accelerated rate over the following 8,000 years during which the recharge rate remains constant at $0.01 \mathrm{~cm} / \mathrm{yr}$.

The simulated potentiometric surface at the present time, however, is still considerably different from the potentiometric surface calculated for steady-state flow with recharge equal to $0.01 \mathrm{~cm} / \mathrm{yr}$ (Figure 16). The present-day potentiometric surface would continue to become more similar to Figure 16 if the period of constant recharge at a rate of $0.01 \mathrm{~cm} / \mathrm{yr}$ were extended. The difference between these two potentiometric surfaces represents degree to which the simulated present-day flow field remains out of equilibrium with the $0.01 \mathrm{~cm} / \mathrm{yr}$ recharge rate.

The recharge rate was increased over the final 2,000 years of the simulation. During this period, the potentiometric surface started to rise and flow rotated back toward the west, demonstrating the reversible nature of changes in the flow field.

The simulated depth to the water table (Figure 22) and the flow vectors (Figure 23) for the present time provide additional insight into the changes that occurred over the first 14,000 years of the simulation. The water table dropped by as much as 55 meters over much of the model region during this period of time. The area of greatest change in flow directions and rates is within and to the south of the WIPP-site boundary. 


\section{Summary}

A series of simulations, including the examples presented here, have improved our conceptual understanding of long-term regional groundwater flow in strata overlying the bedded salt that encloses the WIPP repository. The simulations suggest that the position and shape of the water table, and consequently entire flow system above the salt, is sensitive to small changes in the rate of recharge to the saturated zone. A recharge rate of $0.1 \mathrm{~cm} / \mathrm{yr}$ is sufficient to maintain the water table near the surface. In this case, flow in confined units at depth follows the slope of local topography. A smaller recharge rate of $0.01 \mathrm{~cm} / \mathrm{yr}$ results in a deeper, flatter water table and flow in confined units is along the same direction as the regional slope of the land surface.

The groundwater flow system, however, responds very slowly to changes in recharge occurring over time periods that are thought to be representative of climate change since the end of the Pleistocene. During the transient simulation presented here, an 8,000 year period of recharge at a constant rate of $0.01 \mathrm{~cm} / \mathrm{yr}$ was not long enough to allow the flow field to adjust to that recharge rate. This result suggests that groundwater flow within the region represented by these simulations is always in a transient state of adjustment to long-term changes in climate. Modern flow might, for example, be more representative of past climate conditions than those observed today.

\section{Acknowledgements}

This work is sponsored by the U.S. Department of Energy under contract number DE-AC04-94AL85000. Pat Knupp developed the numerical model used for these simulations and provided the description of SECO-3D used for this presentation. Ellen Dombroski assisted in software implementation of the algorithm. Mike Wallace and Steve Askew helped perform and interpret the simulations. The graphics programming was performed by Rebecca Blaine using IDL, a commercial software package. Bob Holt and Roy Courtright compiled the stratigraphy of the model region. Bob Holt also identified the zones used to assign a hydraulic conductivity distribution to the hydrostratigraphic units. Tina Johnson and Sally Woerner prepared the poster display. 


\section{References}

Bear, J. and Verruijt, A., 1987, Modeling groundwater flow and pollution: D. Reidel Publishing Company, $414 \mathrm{p}$.

Corbet, T. and Wallace, M., 1993, Post-Pleistocene patterns of shallow groundwater flow in the Delaware Basin, southeastern New Mexico and west Texas: New Mexico Geological Society Guidebook, 44th Field Conference, Carlsbad Region, New Mexico and west Texas, p. 321-325.

Davies, P. B., 1989, Variable-density ground-water flow and paleohydrology in the Waste Isolation Pilot Plant (WIPP) region, southeastern New Mexico: U.S. Geological Survey Open-File Report 88-490, $139 \mathrm{p}$.

Hunter, R. L. 1985, A regional water balance for the Waste isolation Pilot Plant (WIPP) site and surrounding area: SAND84-2233. Sandia National Laboratories, Albuquerque, New Mexico.

Knupp, P., 1995, A moving mesh algorithm for 3D groundwater flow calculations with a water table and seepage face: submitted for location.

Powers, D. W., and Holt, R. M., 1990, Sedimentology of the Rustler Formation near the Waste Isolation Pilot Plant (WIPP) site: geological and hydrological studies of evaporites in the northem Delaware Basin for the Waste Isolation Pilot Plant (WIPP), New Mexico, Geological Society of America Field Trip 14, 1990 Annual Meeting, Dallas, Texas.

Swift, P. N., 1993, Long-term climate variability at the Waste Isolation Pilot Plant, southeastern New Mexico, USA: Environmental Management, v. 17. p. 83-97.

Vine, J. D., 1963, Surface geology of the Nash Draw Quadrangle, Eddy County, New Mexico: U. S. Geological Survey Bulletin 1141-B. 


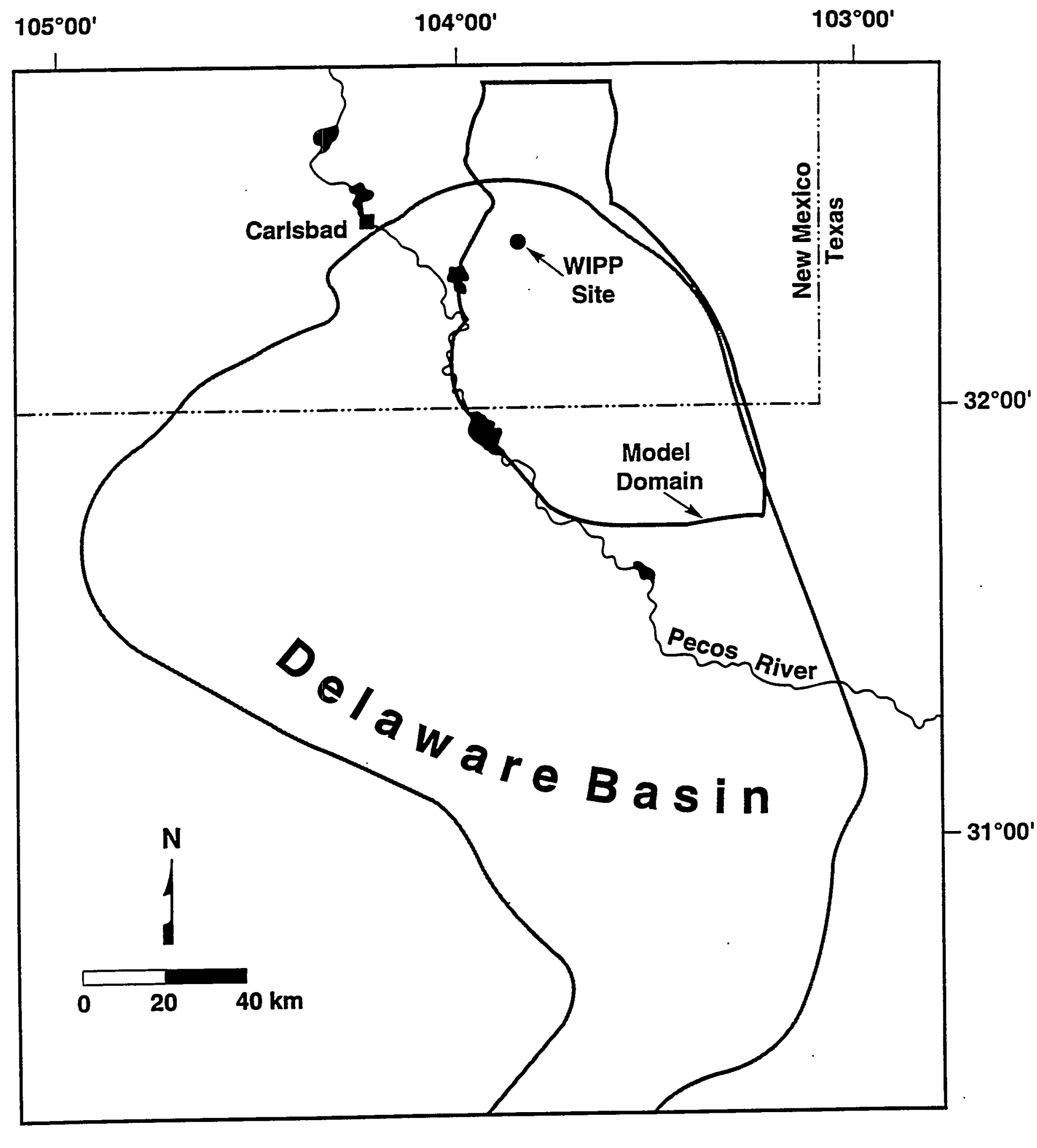

Figure 1

The WIPP repository is located in the Salado Formation, a $600 \mathrm{~m}$ thick deposit of bedded salt, in the northern portion of the Delaware Basin (green line). The boundaries of our numerical model (red line) enclose about 6000 square kilometers. 


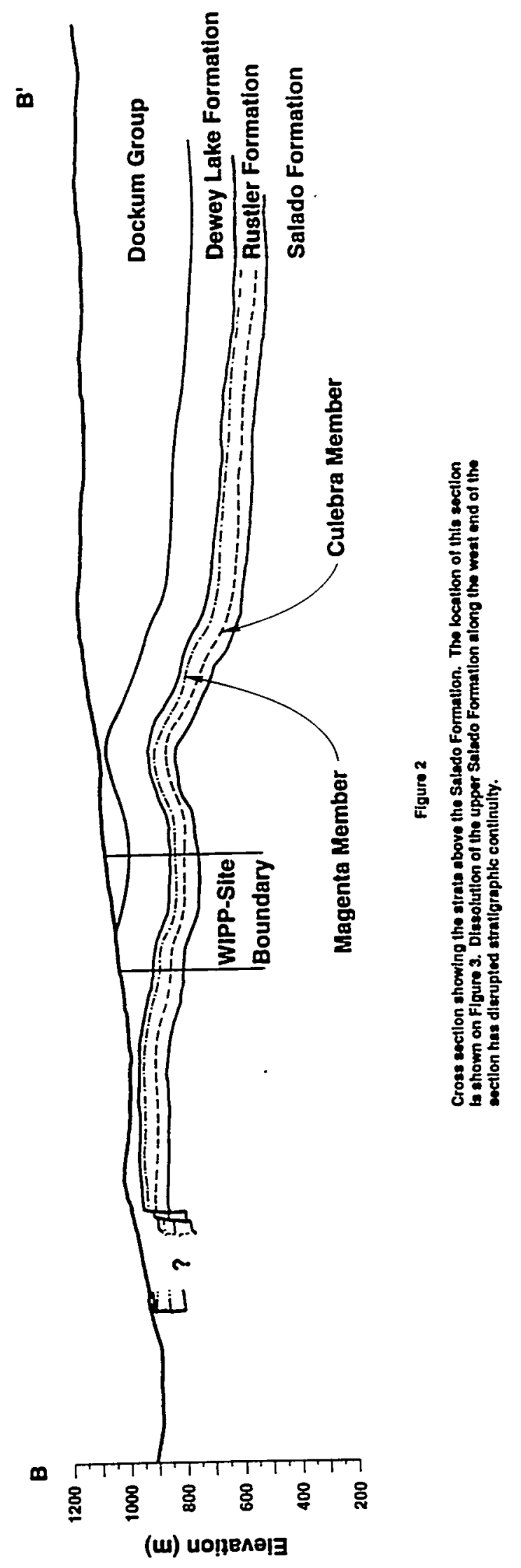




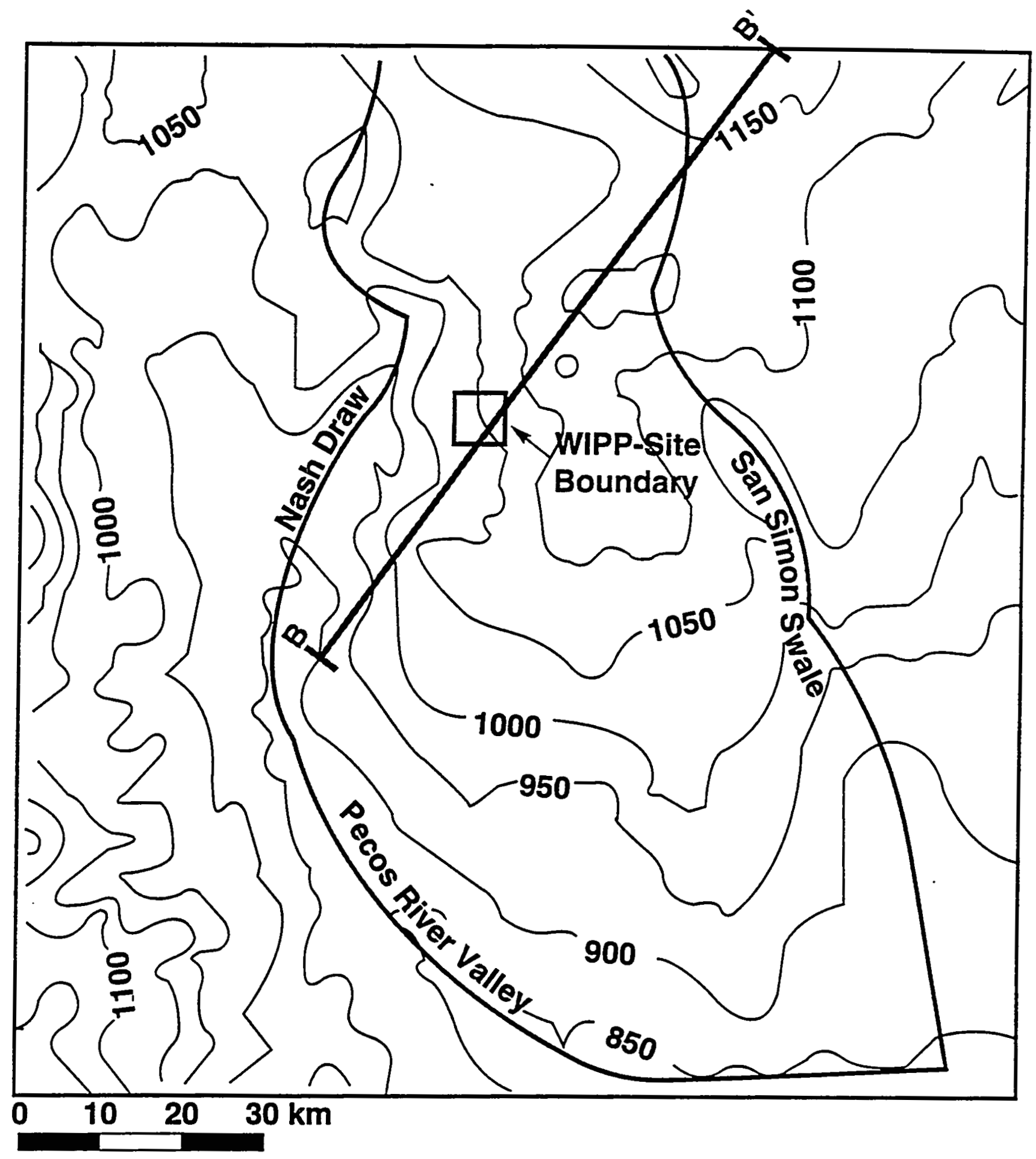

Figure 3

This figure shows the topography of land surface and the lateral boundary of the numerical model (red line). The contour interval for the elevation of the land surface is $\mathbf{5 0}$ meters. The model boundary follows groundwater divides that we believe are valid for the entire period of time simulated. It follows major topographic depressions such as Nash Draw and the Pecos River valley to the west and south and the San Simon Swale to the east. The boundary continues up drainages and dissects topographic highs in the northern part of the model region. We use a no-flow boundary condition along the entire length of the lateral boundary to represent groundwater divides. 


\begin{tabular}{c} 
Stratigraphy \\
\hline Dockum Group \\
\hline
\end{tabular}

Dewey Lake Formation

Forty-Niner Member

Tamarisk Member

\begin{tabular}{c}
\hline $\begin{array}{c}\text { Culebra Dolomite } \\
\text { Member }\end{array}$ \\
\hline
\end{tabular}

\section{Salado Formation}

Hydrostratigraphic Units

Dockum and

Dewey Lake Formation

Anhydrite 5

Mudstone/Halite 4

Anhydrite 4

Magenta Dolomite

Anhydrite 3

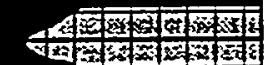

Mudstone/Halite 3

Anhydrite 2

Culebra Dolomite

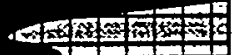

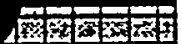

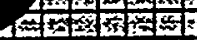

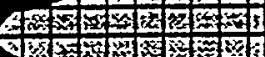

स3

Unnamed

Lower Member

Figure 4

The Rustler Formation is a $\mathbf{1 0 0}$ meter thick sequence of dolomite, anhydrite, mudstone, and halite. The dolomite members are the most permeable units in the formation. We divided the Rustler into nine hydrostratigraphic units for these simulations. The Dewey Lake Formation and the Dockum Group were combined as one additional hydrostratigraphic unit. This unit ranges in thickness from 0 meters in Nash Draw where it has been removed by erosion, to 600 meters in a graben that runs along the southern portion of the eastern model boundary. [Modified from Powers and Holt (1990); original stratigraphy from Vine (1963)]. 


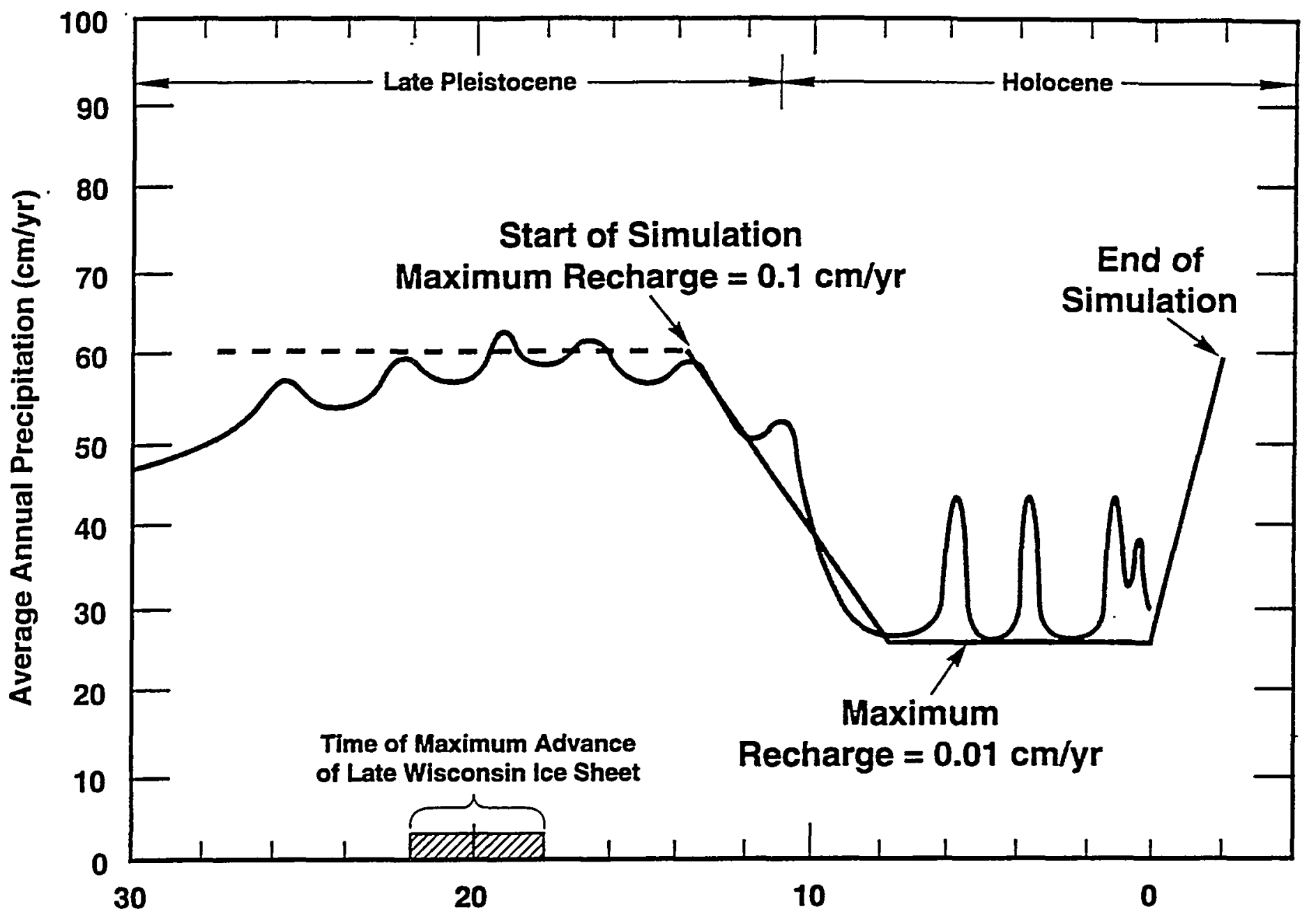

Thousands of Years before Present

Figure 10

The present-day climate at the WIPP is arid to semi-arid. The mean annual precipitation is estimated to be between 28 and $34 \mathrm{~cm} / \mathrm{yr}$ (Hunter, 1985). This figure shows the estimated mean annual precipitation at the WIPP (blue line) during the past 30,000 years (Swift, 1993). The simulations presented here are designed to represent the drying of the climate that is thought to have occurred over the period from 14,000 to 8,000 years before the present.

We don't have a reliable method to correlate mean annual precipitation with the rate at which the groundwater system is recharged. In these simulations we used rates of maximum potential recharge ranging from 0.01 to $0.1 \mathrm{~cm} / \mathrm{yr}$ (red line) to represent the change in climate over the past 14,000 years. The larger rate of recharge is more than sufficient to maintain the water table close to the land surface. The smaller rate results in hydraulic heads in the Rustler Formation that are similar to those observed today. In addition to representing the past climate, we have added a rapid increase in recharge to examine the impact of a hypothetical sharp increase in precipitation over the next several thousand years. 


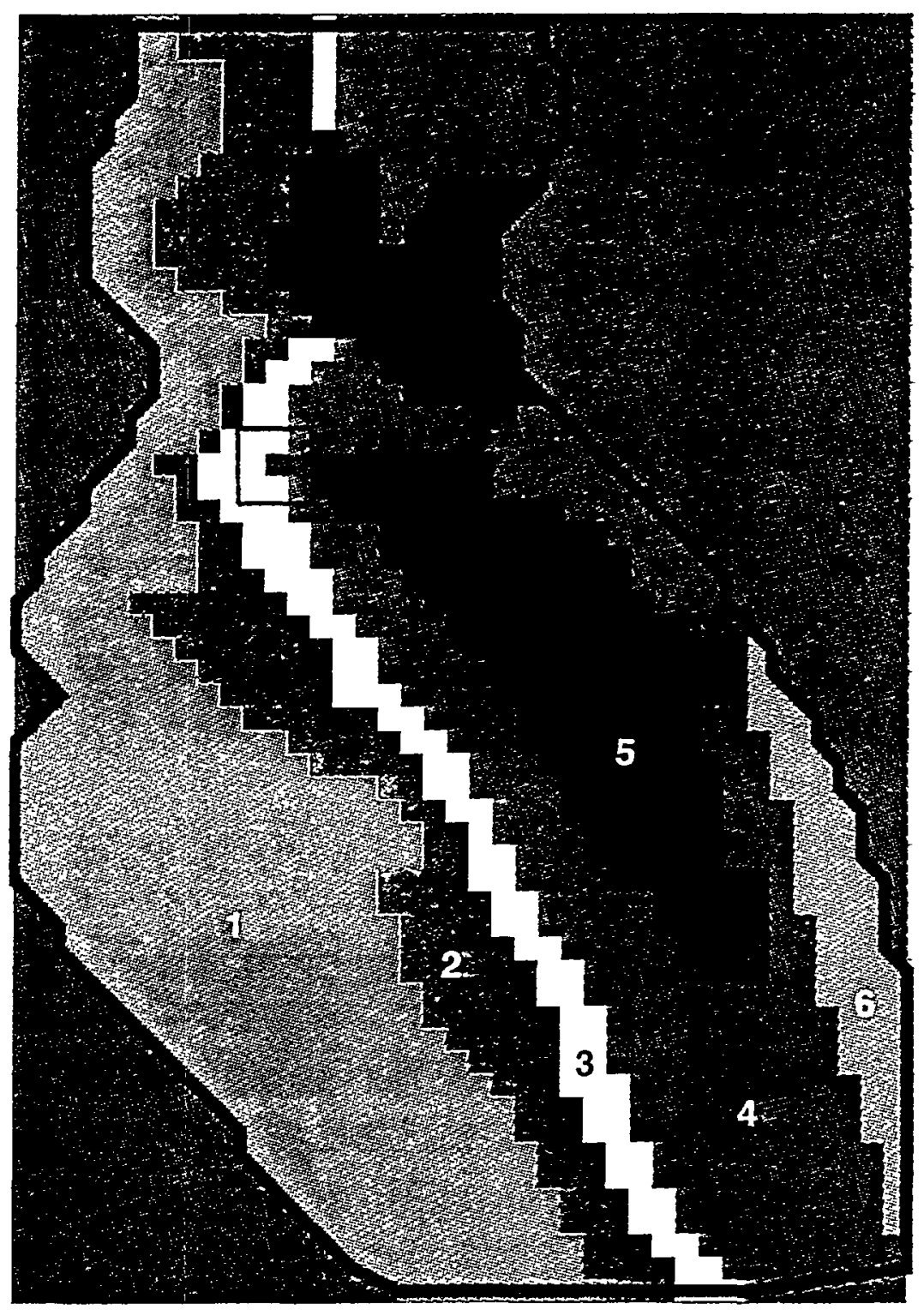

Figure 5

We used a zonation approach to assign a hydraulic conductivity distribution to each model layer in order to represent the effects of depositional setting and post-depositional processes. Zone 1 is a region in which dissolution of the upper Salado has fractured and disrupted overlying strata to the extent that stratigraphic layering is not preserved over long distances. In Zone 2, dissolution of the upper Salado is thought to have fractured the Rustler, but did not disrupt layering. Fractures that pre-date dissolution of the upper Salado are mostly filled with gypsum. These fracture fillings have been removed in Zone 3. Zone 4 represents intact strata. The region occupied by the halite facies of the mudstone/halite layers is indicated by Zone 5 . A Permian-age graben structure is shown as Zone 6. 

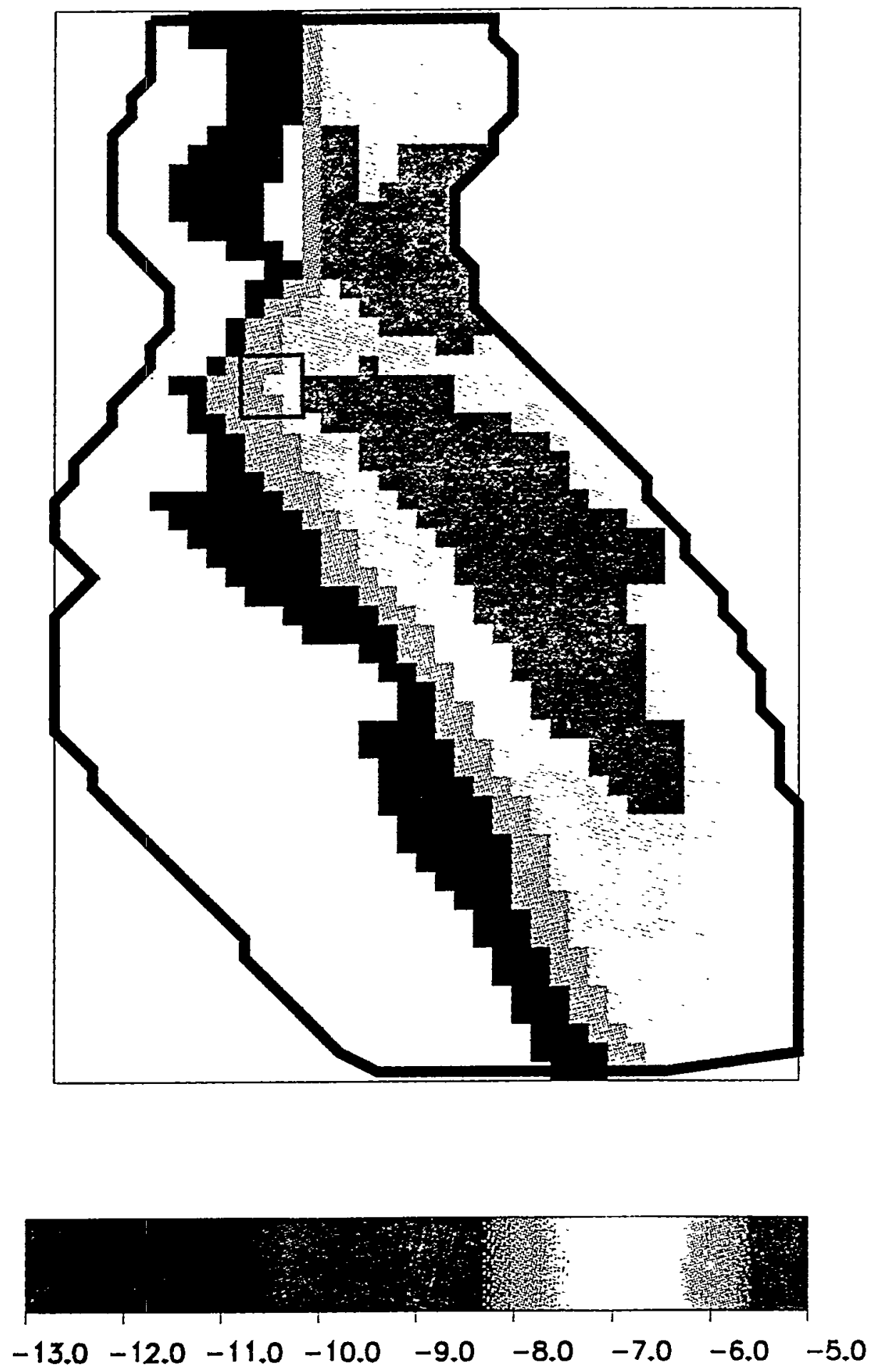

Figure 6

Distribution of Log of Hydraulic Conductivity (meters/second) Used for the Culebra Dolomite 

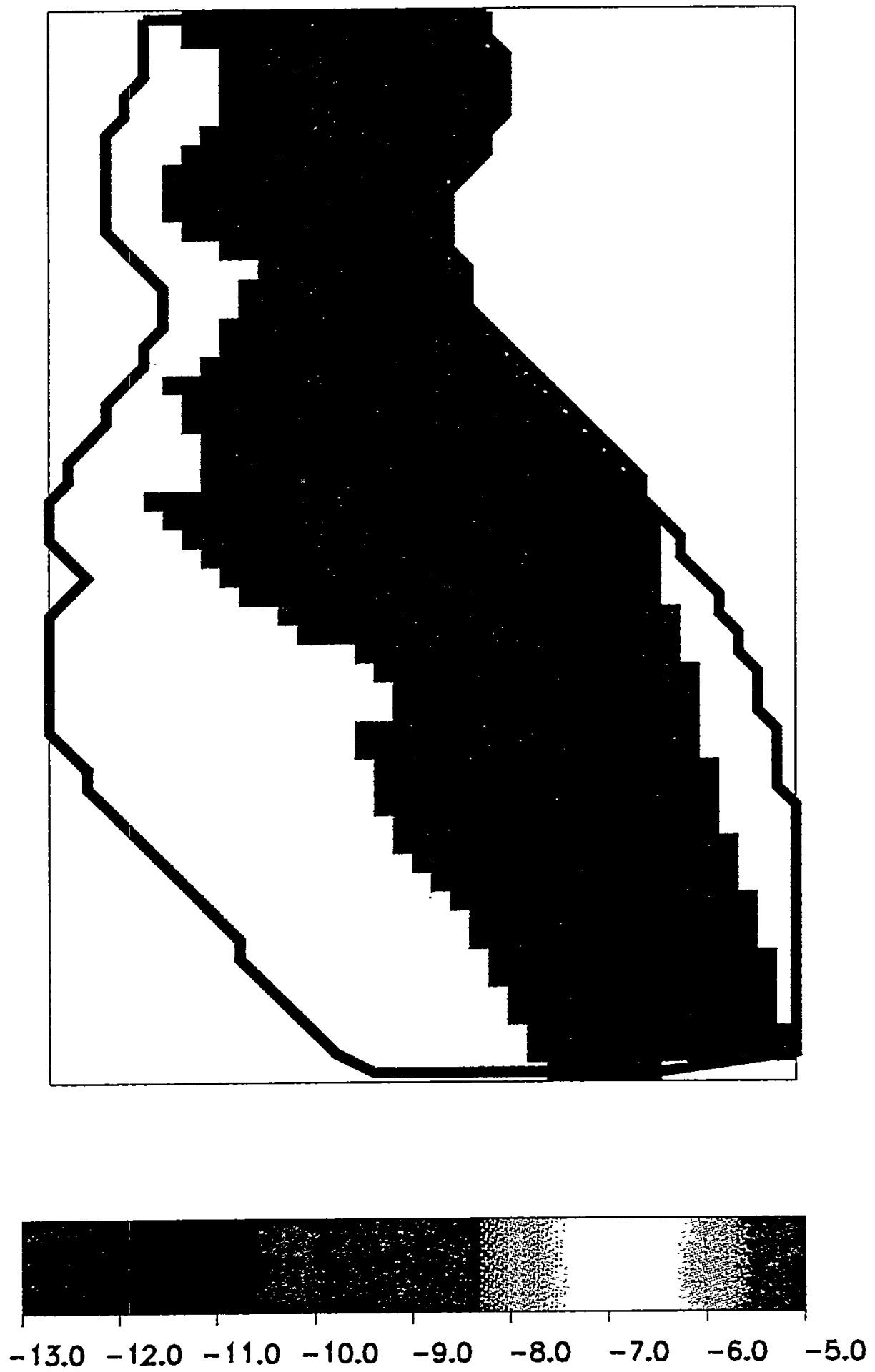

Figure 7

Distribution of Log of Hydraulic Conductivity (meters/second) Used for the Anhydrite Units 

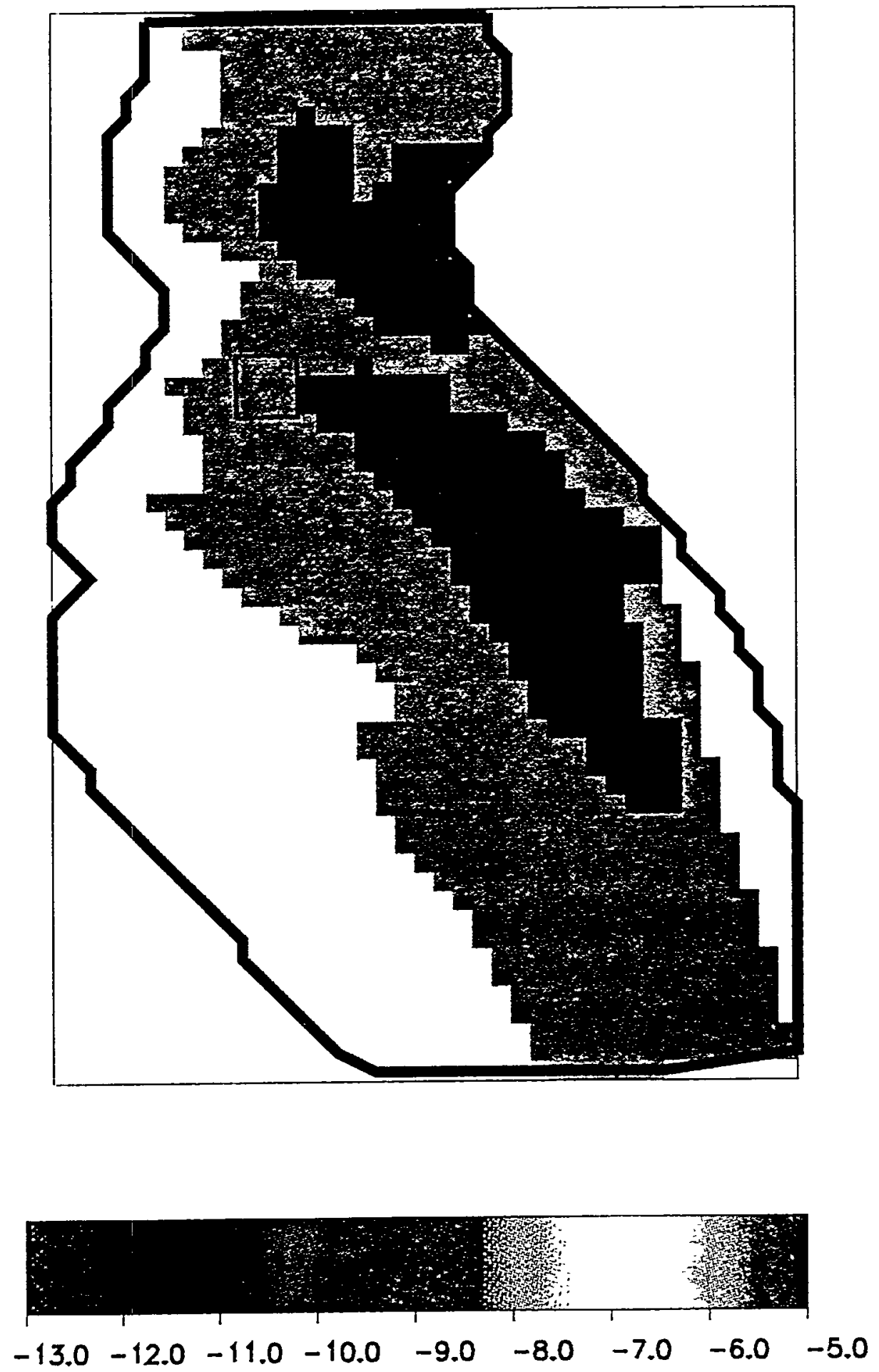

Figure 8

Distribution of Log of Hydraulic Conductivity (meters/second) Used for the Mudstone/Halite Units 

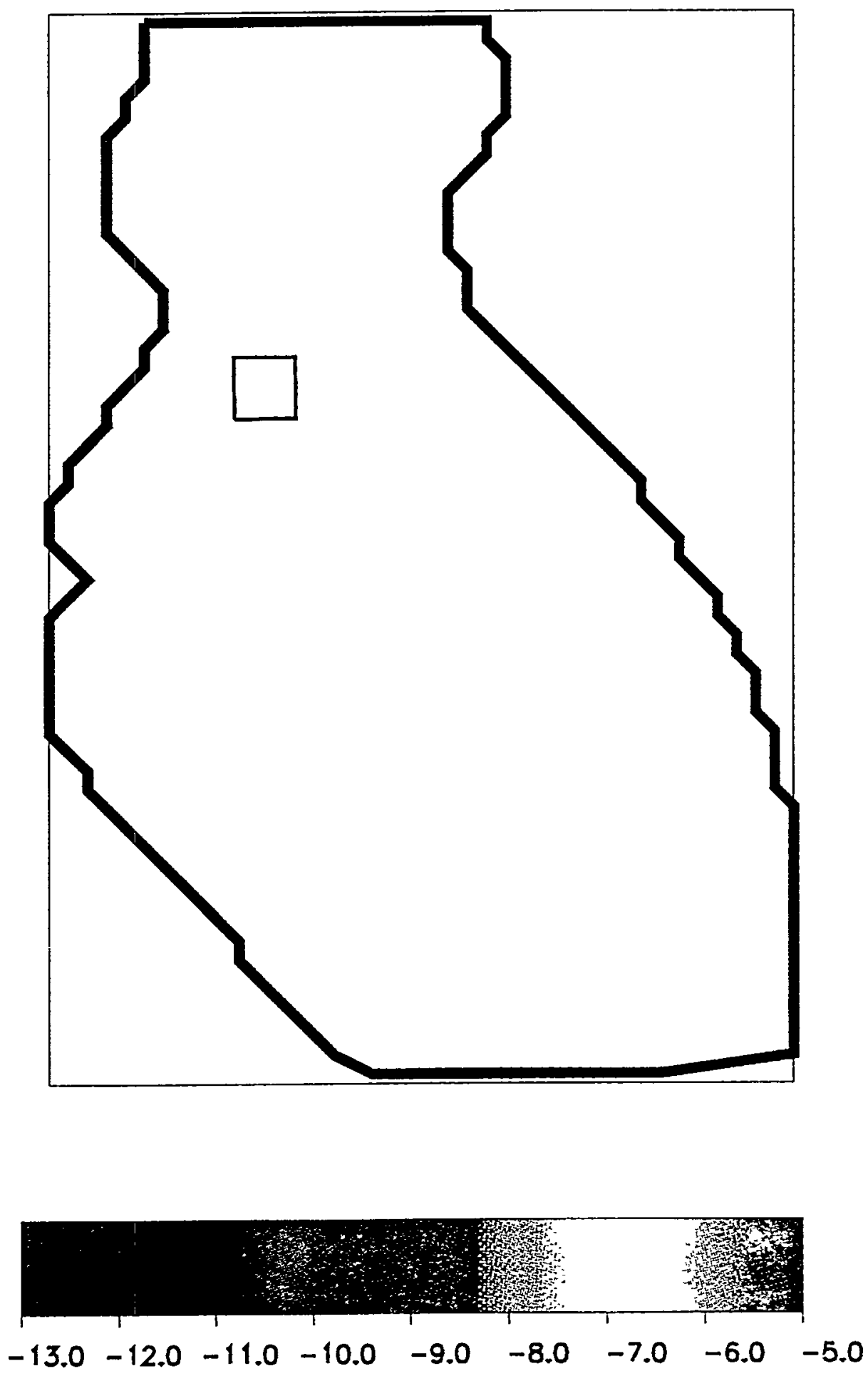

Figure 9

Distribution of Log of Hydraulic Conductivity (meters/second) Used for the Combined Dewey Lake Formation and Dockum Group 

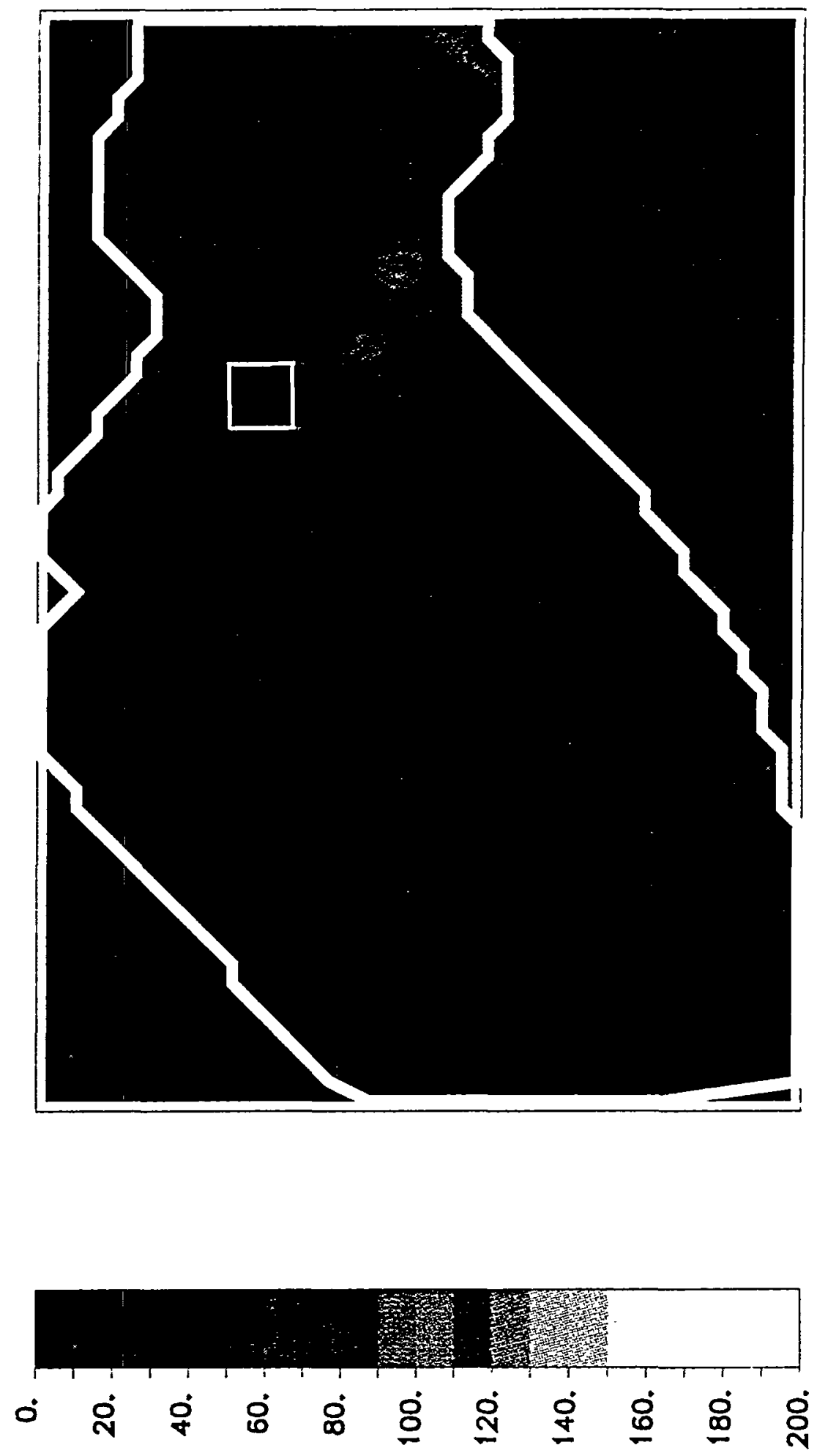

Figure 11

Steady-State Depth to the Water Table (meters) Maximum Potential Recharge $=0.1 \mathrm{~cm} / \mathrm{yr}$ 

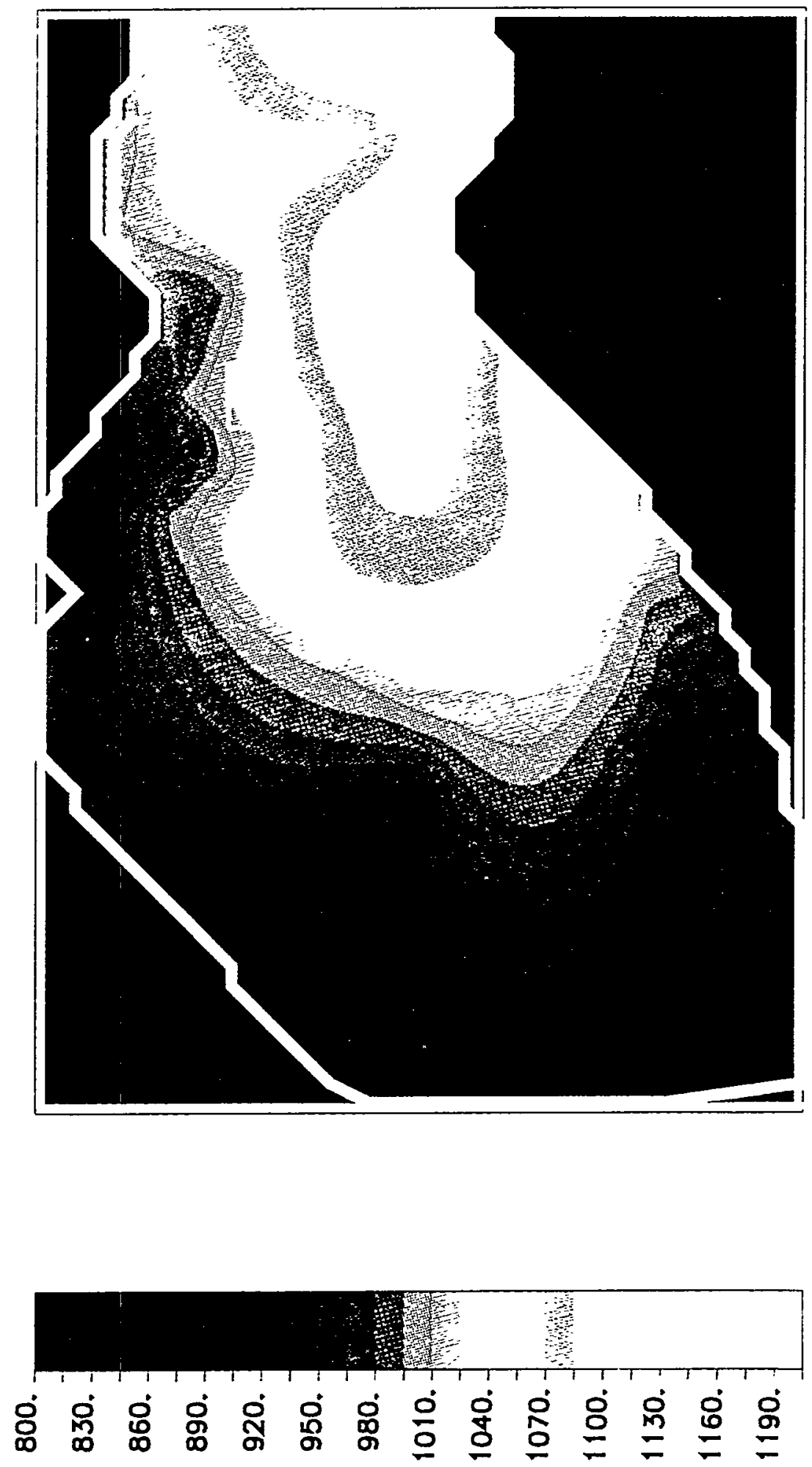

Figure 12

Steady-State Water Table (meters) Maximum Potential Recharge $=0.1 \mathrm{~cm} / \mathrm{yr}$ 

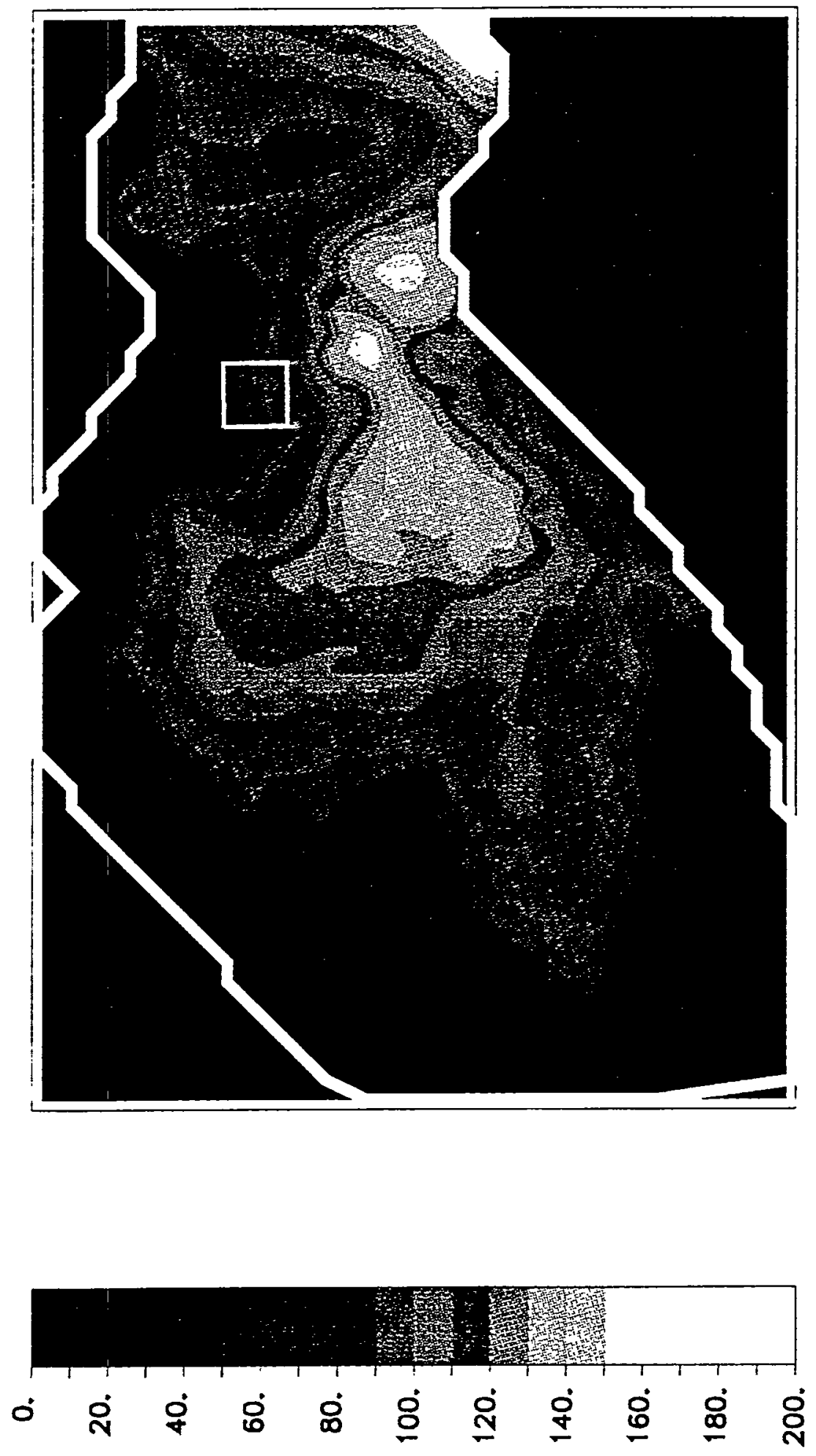

Figure 13

Steady-State Depth to the Water Table (meters) Maximum Potential Recharge $=0.01 \mathrm{~cm} / \mathrm{yr}$ 

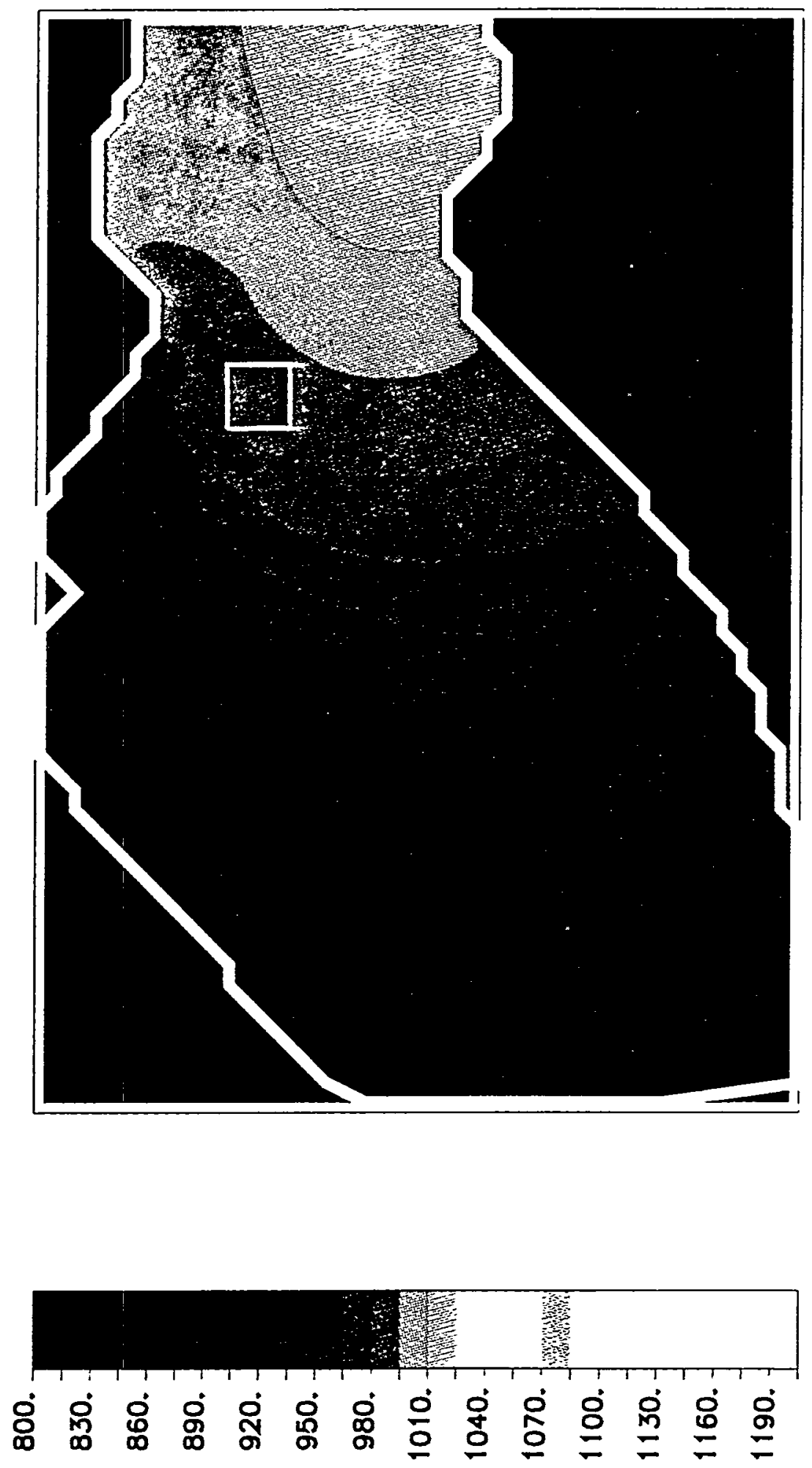

Figure 14

Steady-State Water Table (meters)

Maximum Potential Recharge $=0.01 \mathrm{~cm} / \mathrm{yr}$ 

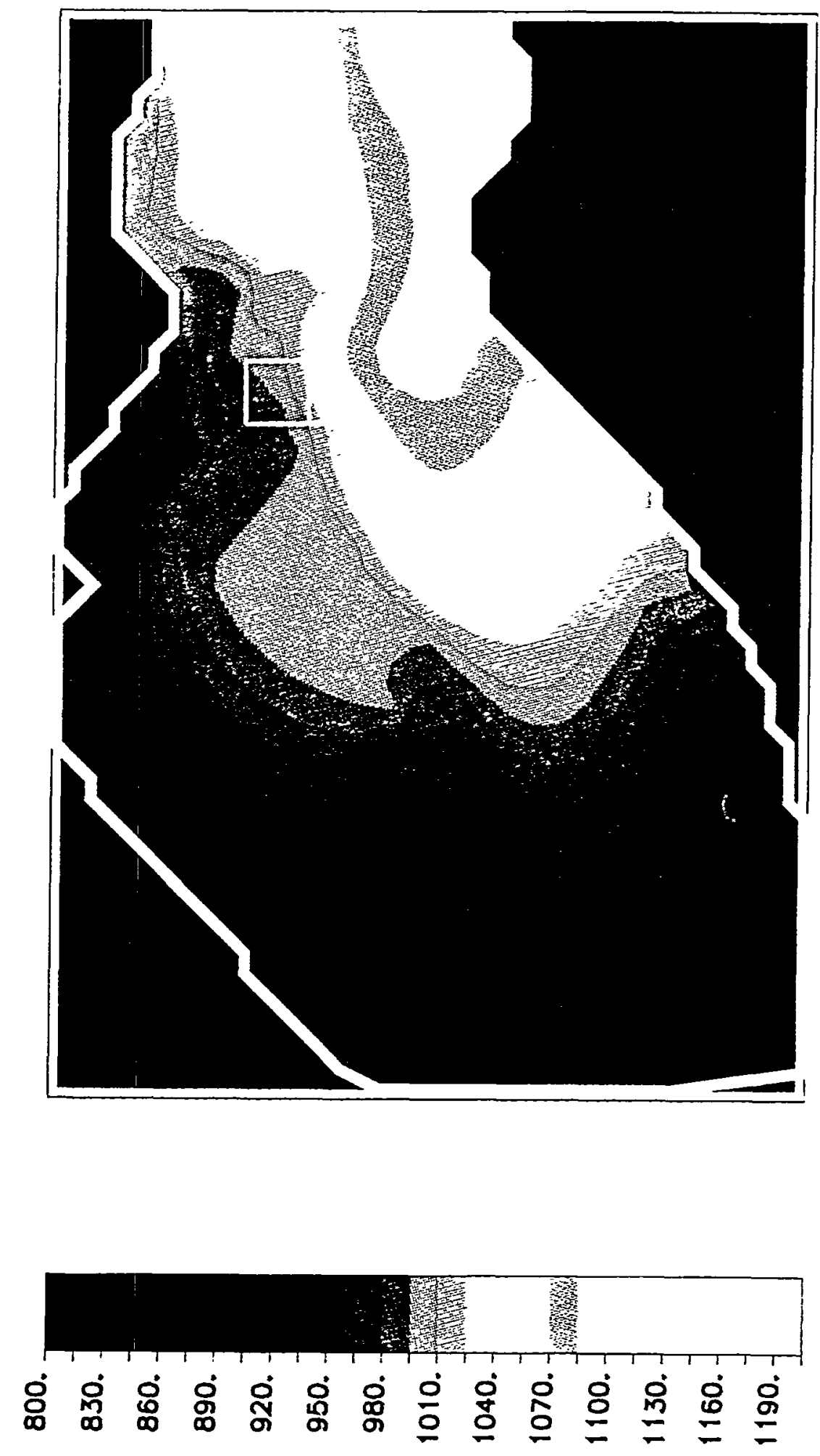

Figure 15

Steady-State Hydraulic Head in the Culebra (meters Maximum Potential Recharge $=0.1 \mathrm{~cm} / \mathrm{yr}$ 

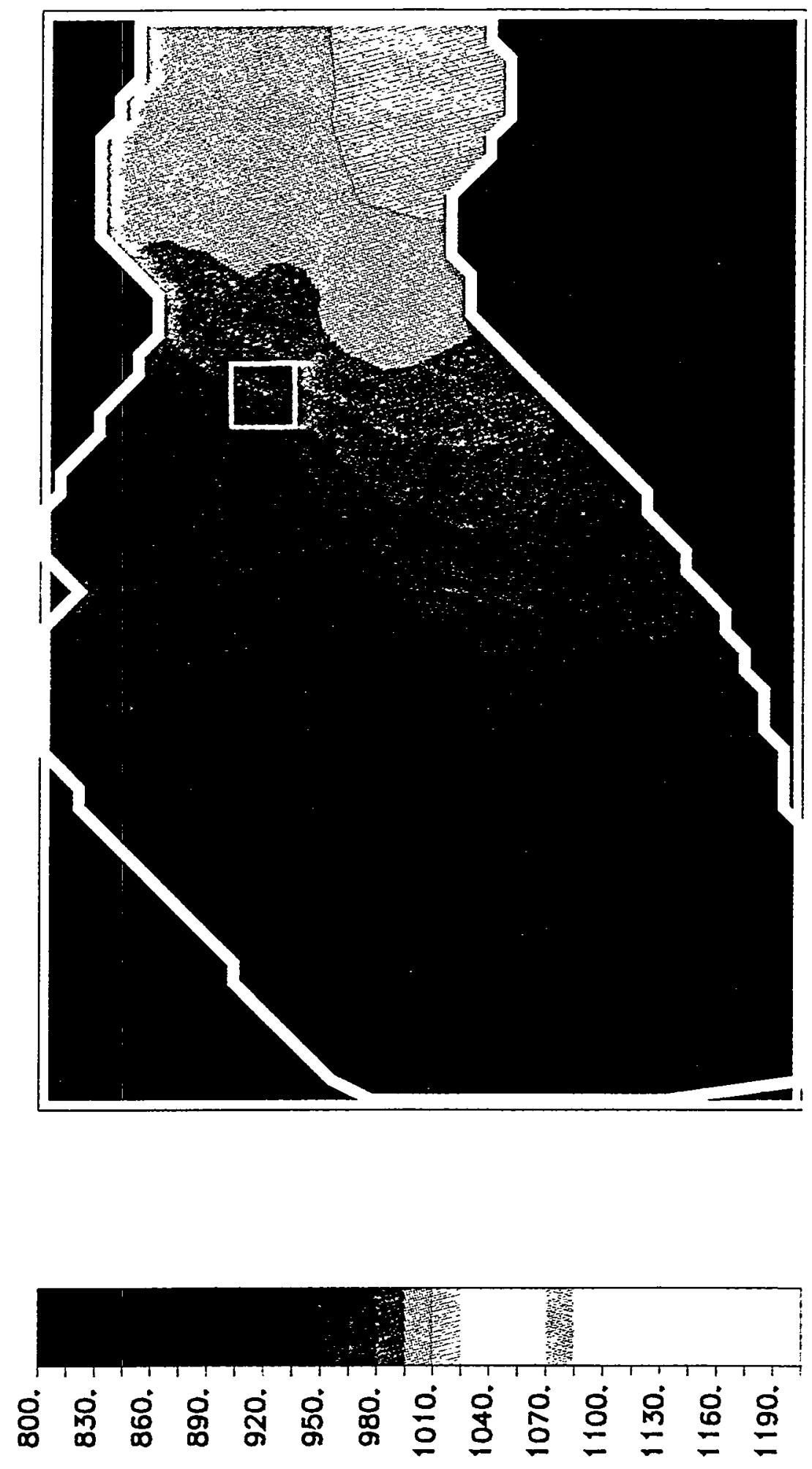

Figure 16

Steady-State Hydraulic Head in the Culebra (meters) Maximum Potential Recharge $=0.01 \mathrm{~cm} / \mathrm{yr}$ 

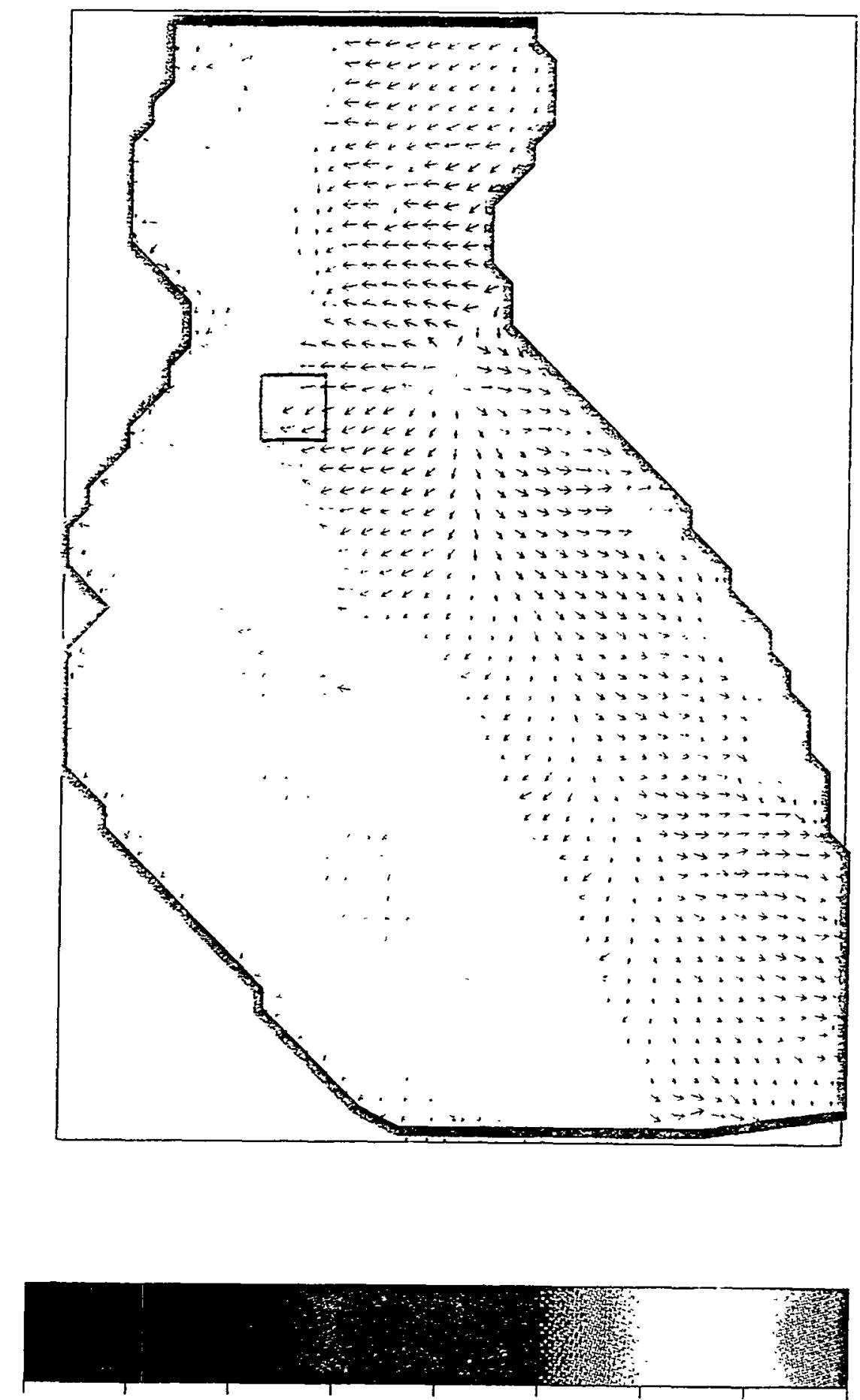

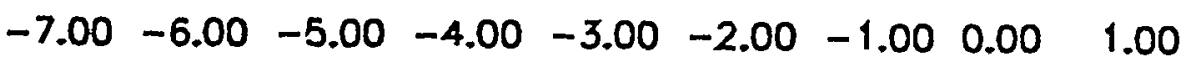

Figure 17

Log of Steady-State Specific Discharge in the Culebra (meters/year) Maximum Potential Recharge $=0.1 \mathrm{~cm} / \mathrm{yr}$ 

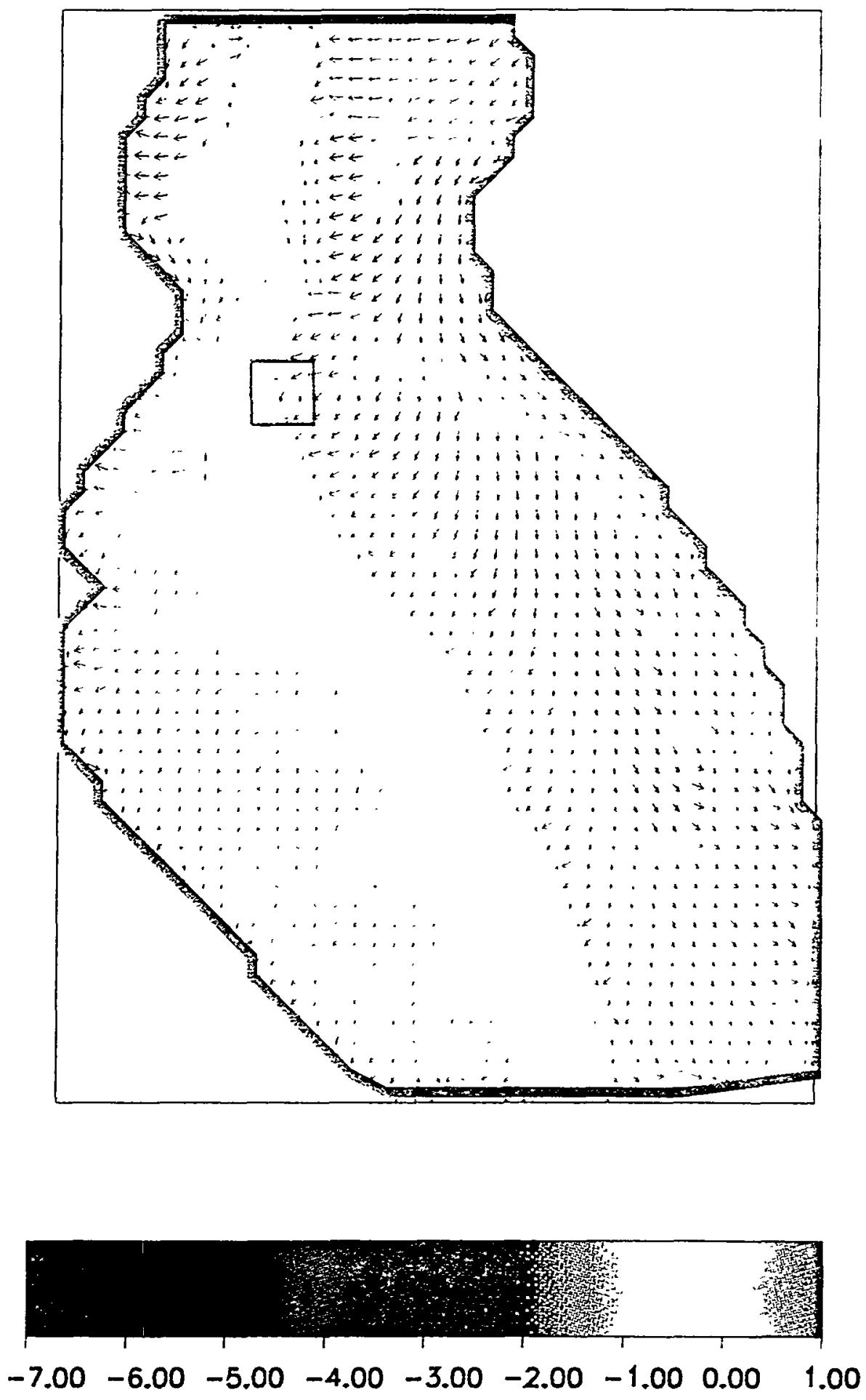

Figure 18

Log of Steady-State Specific Discharge in the Culebra (meters/year) Maximum Potential Recharge $=0.01 \mathrm{~cm} / \mathrm{yr}$ 

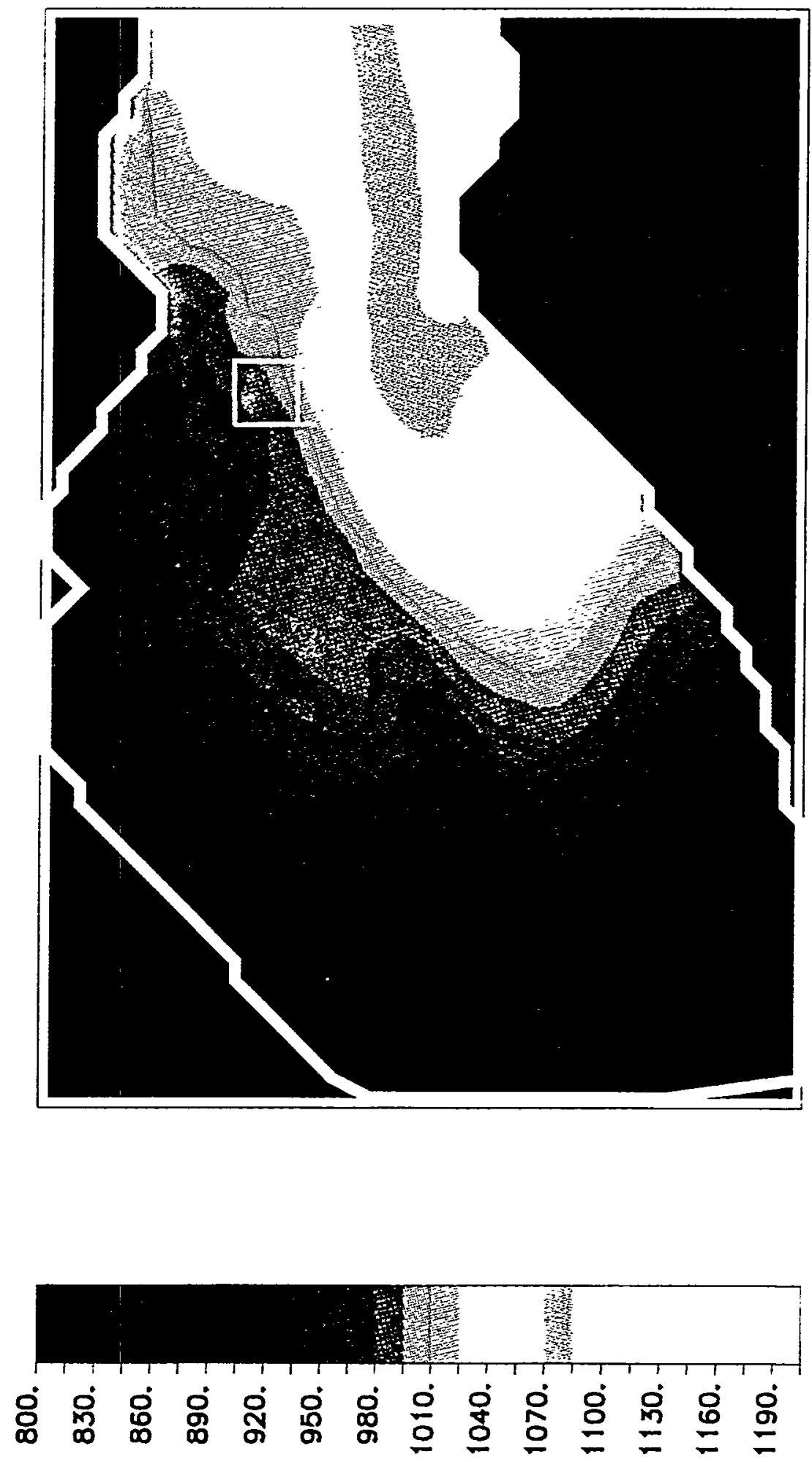

Figure 19

Hydraulic Head in the Culebra (meters) at 8,000 Years Before Present 

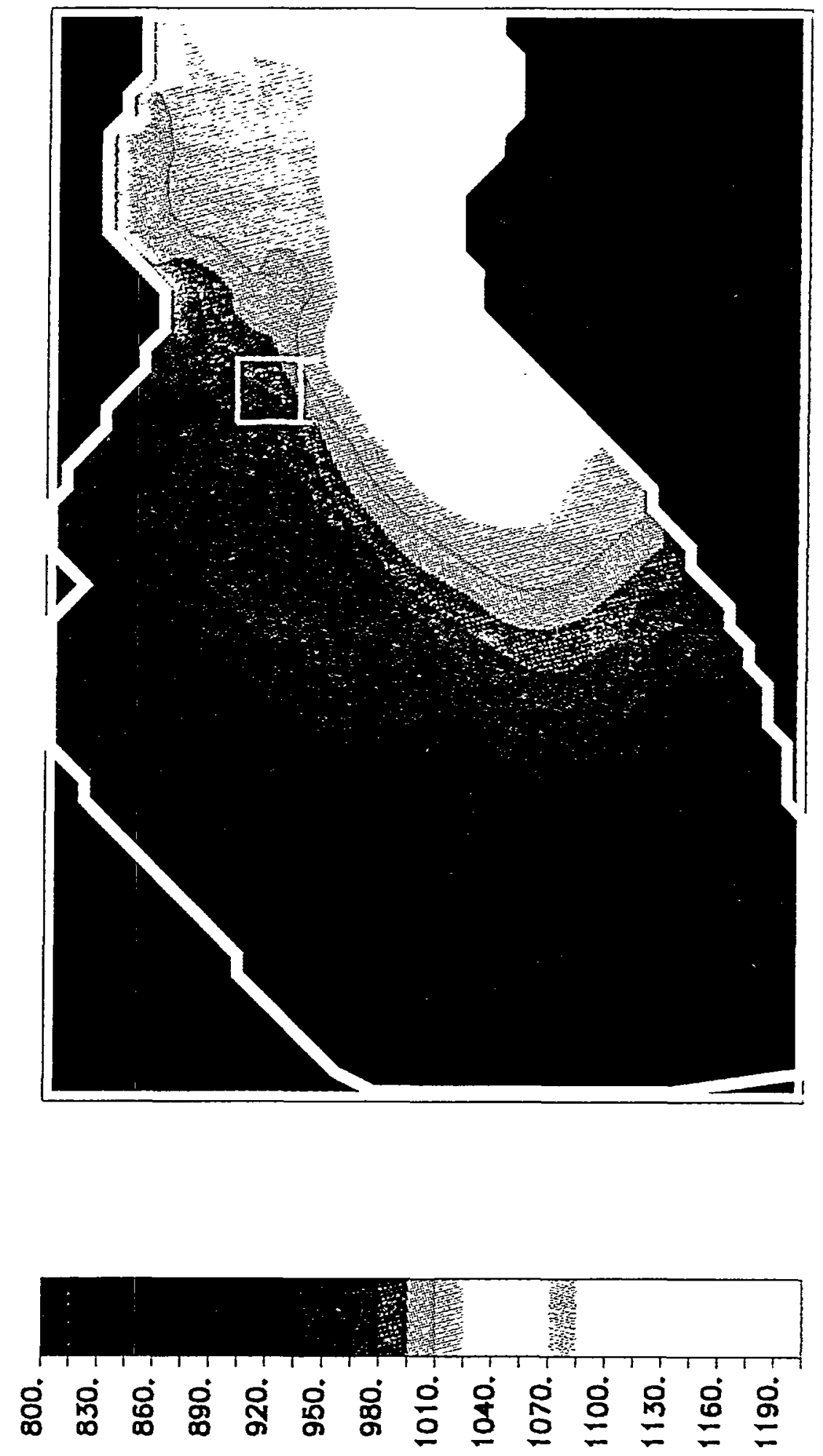

Figure 20

Hydraulic Head in the Culebra (meters) at the Present Time 

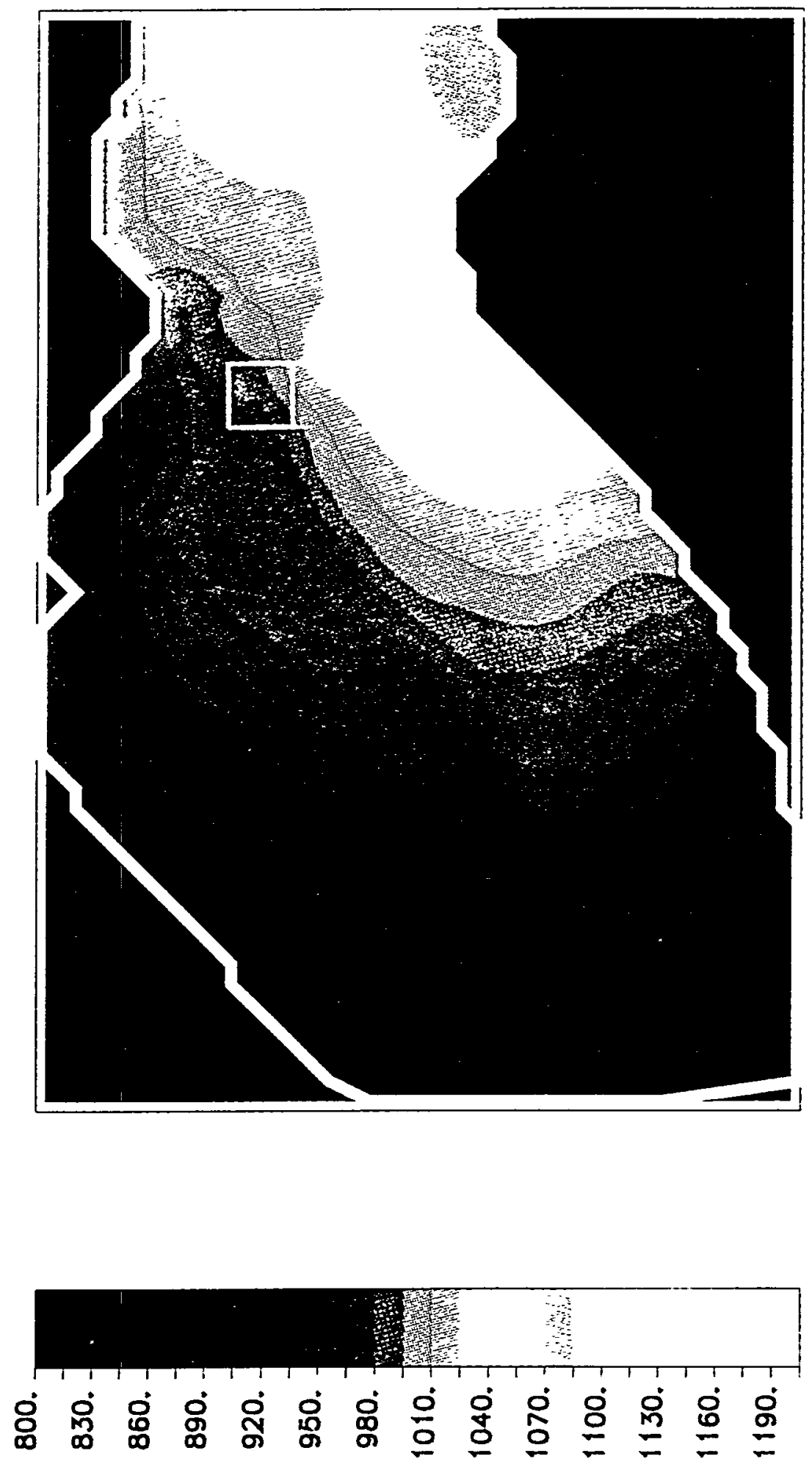

Figure 21

Hydraulic Head in the Culebra (meters) at 2,000 Years in the Future 

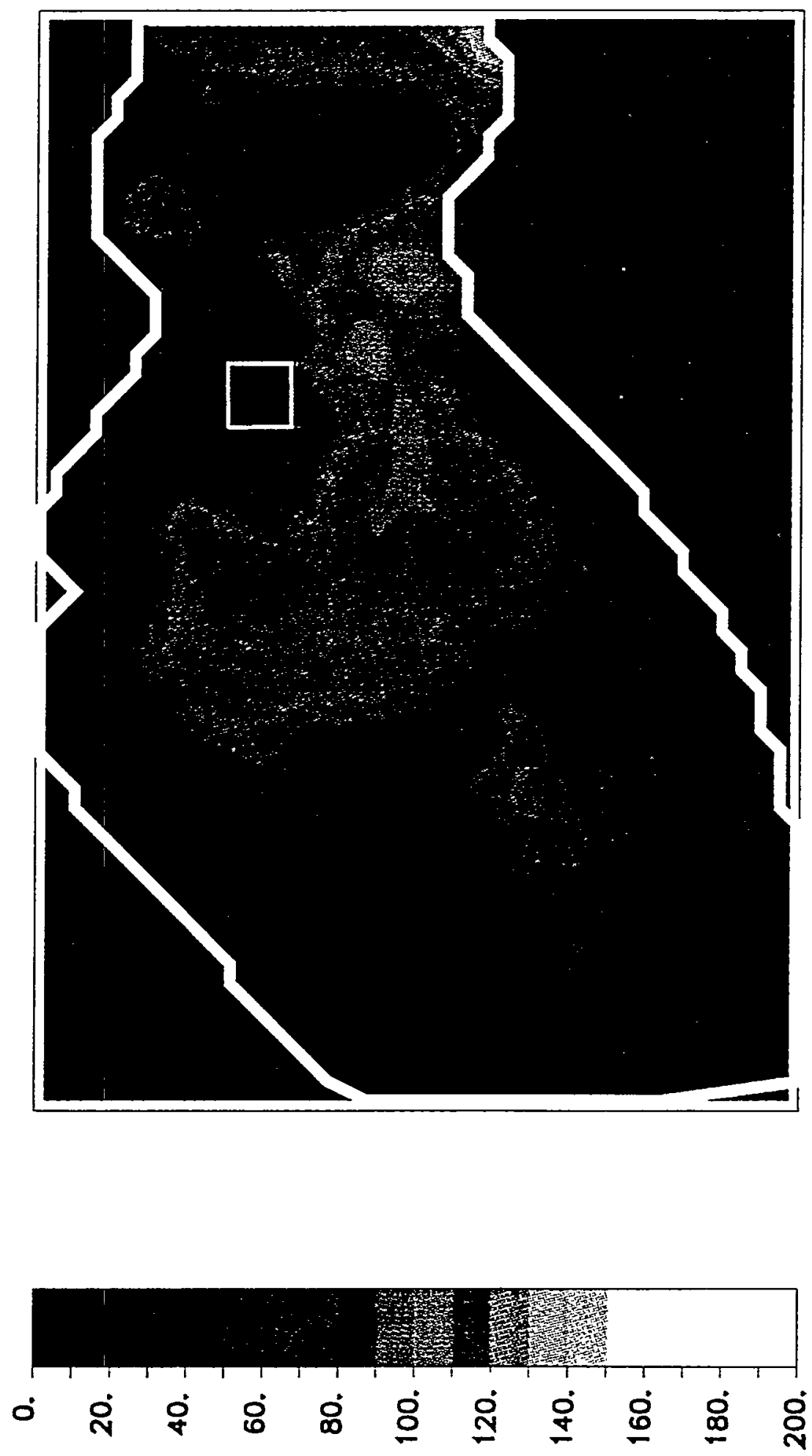

Figure 22

Depth to the Water Table (meters) at the Present Time 

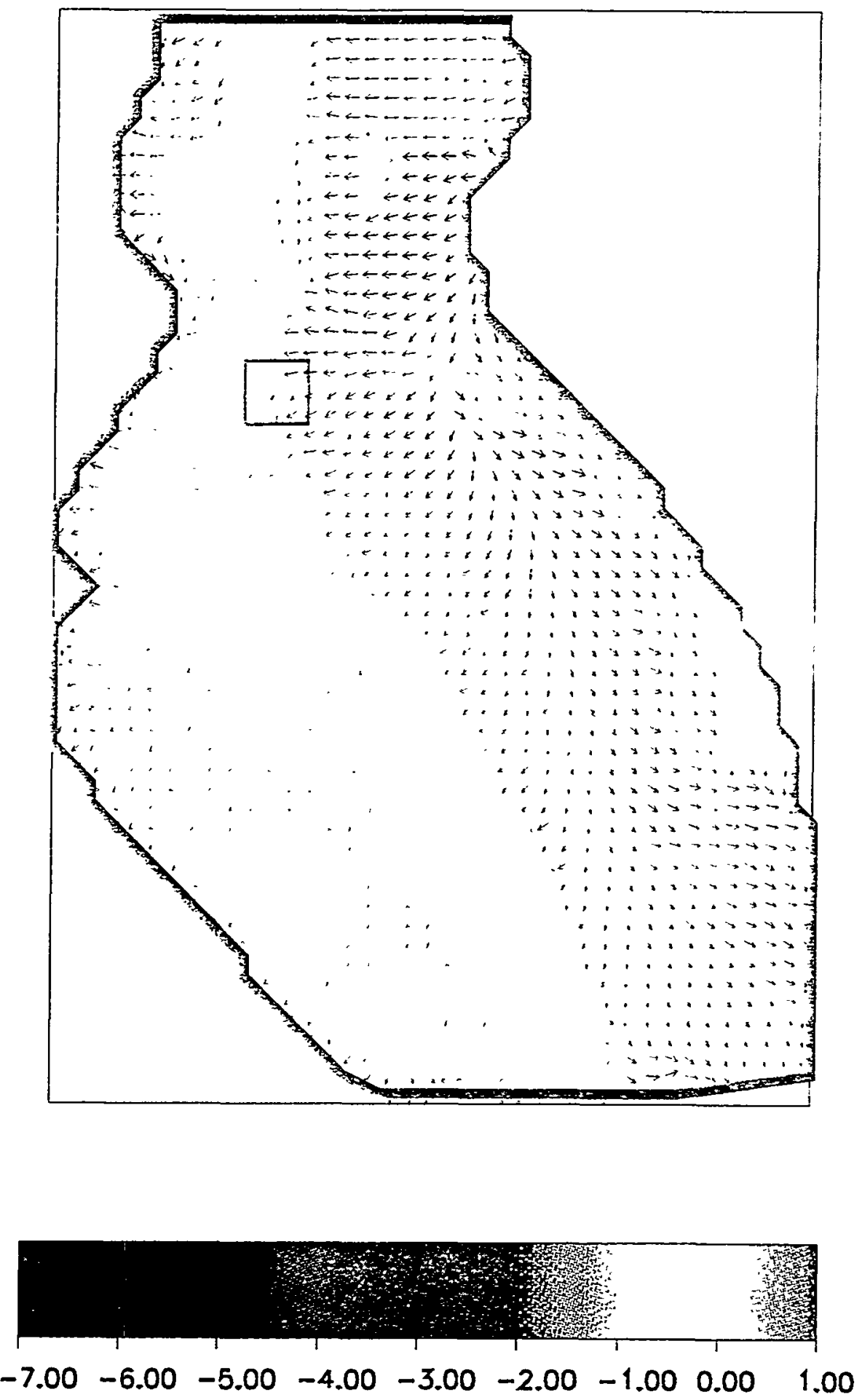

Figure 23

Log of Specific Discharge in the Culebra (meters/year) at the Present Time 